НАВЧАЛЬНИЙ ДІАЛОГ НА УРОКАХ УКРАЇНСЬКОЇ МОВИ

ЯК ЗАСІБ ФОРМУВАННЯ ВМІНЬ ЗДОБУВАЧІВ ОСВІТИ ЗАПОБІГАТИ КОНФЛІКТНИМ СИТУАЦІЯМ ТА ЗАЛАГОДЖУВАТИ ЇХ (НА ПРИКЛАДІ СИТУАТИВНИХ ВПРАВ)

\title{
PRACTICAL DIALOGUE IN THE LESSONS OF UKRAINIAN LANGUAGE AS A MEANS OF FORMING EDUCATION APPLICANTS' SKILLS TO PREVENT CONFLICT SITUATIONS AND ADJUST THEM (AS EXEMPLIFIED BY SITUATIONAL EXERCISES)
}

\begin{abstract}
Устатті авторка відстоює думку про те, що навчальний діалог на уроках української мовиє потужним засобом формування вмінь здобувачів освіти запобігати конфоліктним ситуаціям та залагоджувати їх. Діалог потлумачено як форму мовлення; ситуативно зумовлене спілкування двох або кількох осіб, комунікативні ролі яких змінюються; навчальний діалог як суб'єкт-суб'єктну взаємодію, яка викристапізовується в продуктивну навчальну співпрацю під час організації міжособистісної дискусії в процесі формулювання й розв'язання навчальних завдань, скеровану на формування життєвих компетентностей здобувачів освіти; конфолікт як різновид взаємоді суб'єктів, що характеризується подоланням протидії стосовно протилежно скерованих иілей, інтересів, позичій, поглядів, думок. Авторка доводить, що сучасні модельні програми з української мови для закладів середньої освіти у иілому орієнтовані на види навчальної діяльності, що передбачають діалогову взаємодію здобувачів освіти під час моделювання конфрліктних комунікативних ситуацій, а от у підручниках з української мови че враховано лише почасти; на конкретних прикладах переконує, щоб навчальний діалог на уроках української мови фрормував уміння здобувачів освіти запобігати конфрліктним ситуаціям та залагоджувати їх, завдання, запропоновані в підручниках, мають моделювати життєві ситуації, бути близькими щоденним реаліям життя учнів/ учениць, навчати способам соціальної й комунікативної взаємодії, сприяти набуттю вмінь формувати та аргументовано відстоювати власну позицію, захищати інтереси, орієнтуватися в перебігові комунікації, часто непрогнозованому, розвивати мовлення здобувачів освіти, формувати комунікативний досвід, що в подальшому, під час виникнення конорліктних ситуацій, уможливить ефективне їх розв'язання.

Ключові слова: навчальний діалог, учні/ учениці, урок, українська мова, спілкування, комунікація, ситуативні вправи.
\end{abstract}

$6085 / 2021 / 37.18$

Кулик О.Д.,

докт. пед. наук, доцент, лінгвістики і методики навчання, доцент кафедри професійної освіти Університету Григорія Сковороди в Переяславі
In this article, the author advocates the opinion that a practical dialogue used in the lessons of Ukrainian is a powerful means of forming education applicants' skills to prevent and adjust conflict situations. Dialogue is interpreted as a form of speech; the situationally determined interaction of two or several persons whose communicative roles are changing; a practical dialogue as a subject-object interaction which then crystallizes into fruitful learning cooperation during organization of an interpersonaldiscussion, in the course of formulating and solving practical tasks, the cooperation geared towards forming essential competencies of education applicants a conflict as a kind of interaction between subjects, which is characterized by overcoming counteraction in regard to oppositely directed goals, interests, views and opinions.

The author argues that present-day models of Ukrainian language curricula for institutions of secondary education are generally oriented to kinds of learning activity that envisage dialogic interaction between education applicants when modelling conflict-related communicative situations, but it is taken into account only partially in Ukrainian language textbooks; with specific examples, the author proves that a practical dialogue in the lessons of Ukrainian should form education applicants skills to prevent conflict situations and adjust them, and the tasks suggested in the textbooks should model real-life situations; be similar to everyday reality of students' lives; teach them ways of social and communicative interaction; facilitate acquisition of skills in forming and defending their views, protect their interests, monitor the flow of communication, especially when the situation is unpredictable; develop speech skills of education applicants; form a certain communication experience that would enable them to solve effectively any conflict situations in the future.

Key words: practical dialogue, students/pupils, lesson, the Ukrainian language, communication, interaction, situational exercises.
Постановка проблеми в загальному вигляді. Згідно 3 Державним стандартом базової середньої освіти, затвердженим Постановою Кабінету Міністрів України від 30 вересня 2020 р. № 898, однією (першою) 3 ключових компетентностей, яких мають набути здобувачі освіти впродовж навчання, $€$ «вільне володіння державною мовою, що передбачає вміння здійснювати комунікацію в усній та письмовій фрормах <...; здобувати та опрацьовувати інорормацію 3 різних 〈... джерел
〈...> та використовувати для комунікації в усній та письмовій формах для обстоювання власних поглядів, переконань, суспільних і національних цінностей; 〈...> використовувати мовні засоби для досягнення особистих і суспільних цілей у життєвих та навчальних ситуаціях, творчого самовираження» [1] (курсив наш). Саме тому одним із пріоритетних напрямів навчання української мови в сучасних закладах загальної середньої освіти має бути орієнтування на діалогову 
взаємодію як необхідну умову фрормування у здобувачів освіти вмінь і навичок спілкуватися/комунікувати, оскільки комунікація за своєю суттю є діалоговою. Навчальний діалог, на нашу думку, покликаний активізувати мовлення здобувачів освіти; спонукати бажання й сорормувати вміння вступати в мовленнєвий контакт з іншими, досвід швидко орієнтуватися в невизначеному, непрогнозованому перебігові комунікації; самостійно застосовувати комунікативний досвід в інших сорерах життєдіяльності; розвинути культуру мовлення та ін. Усього вищезазначеного можливо досягти за належної комунікативної практики в процесі розв'язання завдань, що моделюють реальні життєві, зокрема конфрліктні, ситуації.

Аналіз останніх досліджень і публікацій. Феномен діалогу в контексті традиційних і сучасних уявлень тривалий час активно досліджують у різних галузях наук, зокрема в аспекті фрілософії (Є. Андрос, О. Слободянюк, М. Лазарєв, О. Лазарєва, О. Гомілко, І. Зязюн, В. Огнев'юк, В. Озадовська, О. Троїцька, Л. Шашкова, М. Злочевська, С. Черепанова та ін.), психології (А. Грись, Г. Дьяконов, С. Золотухіна, В. Масич, І. Кирилюк, В. Мазяр, О. Мерзлякова, О. Пахомова, М. Тоба та ін.), педагогіки (Л. Зазуліна, П. Кендзьор, В. Масич, І. Романко), лінгвістики (Н. Войцехівська, І. Кушнарьова, Л. Матусевич, В. Шабуніна, Н. Шульжук, Г. Шумицька та ін.), теорії та методики навчання української мови (М. Грудок-Костюшко, І. Зайцева, А. Ляшкевич, С. Мунтян, О. Орлова, Е. Палихата, Н. Ростикус, І. Савчак та ін.), однак значна кількість питань залишається недостатньо вивченою, а надто в умовах відкритості й адаптації освіти до швидко змінюваних вимог суспільства.

Виділення не вирішених раніше частин загальної проблеми. Аналіз наукових праць засвідчив, що ролі навчального діалогу на уроках української мови як засобу фрормування вмінь здобувачів освіти запобігати конорліктним ситуаціям та залагоджувати їх приділено недостатньо уваги.

Мета статті. Мета статті - обґрунтувати переваги застосування навчального діалогу в процесі формування вмінь здобувачів освіти запобігати конфліктним ситуаціям та залагоджувати їх; привернути увагу науковців і практиків до проблеми правильної постановки завдань до ситуативних вправ задля досягнення ефективної комунікативної взаємодії здобувачів освіти під час навчального діалогу на уроках української мови.

Виклад основного матеріалу. 3 опертям на загальновизнані в різних галузях наук (зокрема, лінгвістиці, педагогіці, лінгводидактиці) дефініції діалогу та навчального діалогу в науковій рецепції послуговуватимемося такими робочими визначеннями: діалог - фрорма мовлення; ситуативно зумовлене спілкування двох або кількох осіб, комунікативні ролі яких змінюються (адресат ↔ адресант), за умови визнання учасниками спілкування спільної мети й напряму комунікації; навчальний діалог - суб'єкт-суб'єктна взаємодія вчителя/вчительки (або інших дорослих) з учнями/ученицями, учнів/учениць між собою, яка викристалізовується в продуктивну навчальну співпрацю під час організації міжособистісної (внутрішньогрупової/внутрішньокласної) дискусії в процесі фрормулювання й розв'язання навчальних завдань, скерована на фрормування життєвих компетентностей здобувачів освіти.

Важливе місце навчальному діалогові відведено в сучасних модельних програмах мовнолітературної освітньої галузі. Наприклад, з-поміж видів навчальної діяльності, що уможливлюють досягти очікуваних результатів навчання, автори програм з української мови для 5-6-х класів пропонують:

- застосування прийомів активного слухання в діалозі; відповіді на запитання за змістом почутого/прочитаного/переглянутого (індивідуально, у парах, групах); фрормулювання запитань до почутого/прочитаного/переглянутого (індивідуально, у парах, групах); обмін враженнями, думками, зокрема у цифровому середовищі, щодо почутого/прочитаного/переглянутого; обговорення та обґрунтування актуальності теми та основної думки почутого/прочитаного/переглянутого; обговорення почутого/прочитаного/переглянутого в контексті життєвого досвіду; дискусія; публічний виступ, зокрема декламування, презентація тощо; театралізація; рольова гра; складання та обговорення переліків творів для читання в колі родини, друзів із метою популяризації; обговорення, зокрема в цифровому середовищі, читацьких уподобань і вражень; інтерв'ю; мовні ігри; проєкти, зокрема театральні, медіа, літературні, ігрові, дослідницькі, інорормаційні та ін. [2];

- моделювання ситуацій, що передбачають етикетні фрункції займенників (займенники тu і Bu; уживання займенників він, вона, вони у присутності людей, на яких вони вказують, тощо); обговорення проблем міжетнічної комунікації в українському суспільстві; висловлення власної думки щодо прочитаного й обстоювання їі тощо; виявлення ознак переконливості, аргументованості; розрізнення невербальних засобів (інтонації, сили голосу, логічного наголосу, темпу, паузи, міміки, жестів, пози), використаних для передавання прихованого змісту; поставлення запитань із метою отримання інсрормації та ін. [5];

- висловлення міркувань та відповіді на запитання за змістом висловлень відомих людей про значення мови в житті людини й суспільства (усно); обмін думками на теми, пов'язані із ціннісними орієнтирами; колективне складання словничка найпоширеніших етикетних фрормул (привітання, прощання, вибачення, висловлення вдячності та ін.); 
складання мінівисловлення 3 урахуванням ситуації спілкування за ілюстрацією (або коміксом); розв'язання ситуативних завдань, пов'язаних із неврахуванням умов спілкування; виконання проєкту (участь у теле- чи радіопередачі, інтерв'ю про значення української мови в житті нашого народу) та ін. [6];

- бесіда за проблемними моментами викладу; створення системи запитань; взаємоопитування; трансорормація осмисленого тексту викладу; створення діалогів за опорним плакатом; створення коротких висловлень і написання коротких творчих робіт задля поглиблення уявлення про репліку в діалозі; ігри (розігрування типових етикетних сцен); діалоги і репліки для коміксів; продовження відомих серіалів чи створення ремарок для них; спростування хибних тверджень й ін. [7].

Кожний $з$ означених видів навчальної діяльності передбачає комунікативну взаємодію «вчитель(ка) ↔ учні/учениці» або «учні/учениці між собою», або «дорослий(ла) ↔ учні/учениці», а отже, хоч-не-хоч, здобувачі освіти залучені до навчального діалогу. Уважаємо, що перевагою сучасних модельних програм 3 української мови $€$ деталізація ключових акцентів компетентнісного підходу до навчання, а саме: 3 «вивчення теоретичного матеріалу $\rightarrow$ засвоєння його в процесі виконання вправ $\rightarrow$ застосування в мовленнєвій практиці» на «вивчення теоретичного матеріалу $\rightarrow$ засвоєння його в процесі виконання вправ, скерованих на розв'язання комунікативних завдань, максимально наближених до реальних життєвих ситуацій $\rightarrow$ широке застосування у мовленнєвій практиці». Результатом такої «деталізації» має стати операціональна та оцінна готовність і здатність здобувачів освіти легко включатися в реальні комунікативні процеси, продуктивно мовленнєво взаємодіяти у великих і малих групах із урахуванням ситуації, умов спілкування, часу, простору, ступеня відкритості, соціального статусу, позиційних ролей та можливостей їх варіювання, симетрії чи асиметрії інтерактивності комунікантів та ін.

Конфрлікт - одна з форм вияву соціальних відносин. Кожна людина час від часу прямо чи опосередковано стає учасником конфлікту. У підлітковому віці конфрлікт є однією з умов соціалізації особистості. У соціології термін «конфллікт» має кілька визначень, однак, оскільки в межах пропонованої рецепції нашу увагу закцентовано на змістові навчання української мови в аспекті формування у здобувачів освіти ключових компетентностей, що передбачають, зокрема, вільне володіння державною мовою, вміння «відповідально 〈... використовувати мовні засоби для досягнення особистих і суспільних цілей у життєвих та навчальних ситуаціях, творчого самовираження» [1] (курсив наш), а життєві та навчальні ситуації так чи так передбачають наявність кон- фрліктних, обмежимося таким: конфрлікт - це різновид взаємодії суб'єктів, що характеризується подоланням протидії стосовно протилежно скерованих цілей, інтересів, позицій, поглядів, думок. Конфлікт фрормує негативні настанови учасників стосовно одне одного, провокує «викривлення» інорормації, призводить до неправильних інтерпретацій подій/ситуацій/намірів, порушує цілепокладання й поведінку учасників. Загальновідомо, що конструктивне розв'язання конорлікту можливе лише в процесі ефективної комунікативної взаємодії його учасників. На це орієнтують й автори модельних програм мовно-літературної освітньої галузі, зокрема «пропоновані види навчальної діяльності дають змогу сорормувати вміння зосереджувати увагу, конструктивно керувати емоціями, адекватно реагувати на конфрліктні ситуації, налаштовуватися на конструктивну комунікацію» [2]; «добір і застосування стратегій розв'язання конфрліктів відповідно до різних ситуацій» [5]; «усвідомлення ролі володіння рідною мовою для запобігання консрліктам. Готовність до пошуку різноманітних способів розв'язання комунікативних проблем», «складання висловлення, пов'язаного 3 конкретною життєвою ситуацією, з вибором синтаксичних одиниць (зокрема, 3 метою уникнення конорліктних ситуацій)» [6] та ін.

Таким чином, види навчальної діяльності, що передбачають діалогову взаємодію (див. вище цит. з Програм) під час моделювання конорліктних комунікативних ситуацій, акцентують увагу здобувачів освіти не лише на відтворенні теорії в процесі виконання завдань, а «змушують», спонукають спілкуватися у ситуаціях, які виходять за межі звичного/комфортного способу життя, що, своєю чергою, стимулює мовну й мовленнєву реслексії (детальніше див. [3]). Спочатку здобувач, добираючи слова, говорить повільно, виважено, ніби трохи затинається (орієнтується у ситуації спілкування), існує розрив у часі між фрормуванням змістового боку висловлення і його мовним наповненням, надалі процес вибору слів (із центру й периорерії лексикону) прискорюється, автоматизується, добір мовних засобів стає свідомим, обґрунтованим, виваженим, розрив у часі стає все більш незначним відповідно до рівня мовленнєвого розвитку й комунікативного досвіду, якого досягає здобувач освіти в процесі навчання української мови.

Здавалося б, оскільки сучасні програми у цілому орієнтують учасників освітнього процесу до активної комунікативної взаємодії, проблема застосування навчального діалогу на уроках української мови як засобу фрормування вмінь здобувачів освіти запобігати конорліктним ситуаціям та залагоджувати їх мала би бути вирішена, однак аналіз змістового наповнення підручників нового покоління з української мови для закладів 
середньої освіти викликає сумніви щодо остаточного її розв'язання.

По-перше, завдань, що передбачають навчальний діалог, достатньо, а от таких, що моделюють конфрліктні ситуації та закликають здобувачів освіти залагоджувати їх, або зовсім мало, або взагалі немає. По-друге, фрормулюючи завдання, автори підручників, на наше переконання, не вповні усвідомлюють (хоча при цьому чітко дотримуються вимог Програм), якого результату, реального чи фрормального, досягнуть учні/учениці після його виконання. Правильно поставлене завдання сприяє тому, що навчальний діалог стає не лише своєрідною інтелектуальною грою, а й сприяє розвиткові мовленнєвої активності та набуттю досвіду комунікативної взаємодії учнів/учениць, отже, воно має активізувати пізнавальну активність здобувачів освіти, вести до отримання нових знань або створення нових засобів їх пошуку, фрормулювання самостійних висновків, усвідомлення того, наскільки тісно отриманий результат пов'язаний із задоволенням певних важливих життєвих потреб.

Наведемо приклади завдань, наявних у підручниках з української мови для закладів середньої освіти, в яких учнів/учениць спонукають до навчального діалогу, однак не акцентують увагу на тому, що ситуація $є$ конфрліктною, або уможливлюють фрормальний підхід до його розв'язання (прізвища авторів підручників не вказуємо з етичних міркувань).

Ситуація. Уявіть, що ваш друг чи подруга не вважає наполегливу працю достатньою передумовою для досягнення успіху. Ви ж дотримуєтеся іншої думки. Складіть і розіграйте за особами можливий у цій ситуації діалог дискусійного характеру (8-10 реплік). Використайте одне чи кілька поданих узагальнено-особових речень.

На нашу думку, саме так поставлене завдання не описує «ідеальну картину» конфрлікту, адже в умовах навчального середовища ніхто зі здобувачів освіти не відчуває протилежно скерованих цілей, інтересів, позицій, поглядів, думок: по-перше, діалог, змодельований у конфлікті з другом/подругою, як правило, нівелюється, оскільки щирих «конолліктних» емоцій учасники не відчувають, по-друге, здобувач має відстоювати нав'язану йому позицію «ви ж дотримуєтеся іншої думки». Чи буде учень/ учениця наполегливо відстоювати думку, яка для нього/неї особисто є неприйнятною? Діалог, звісно, складуть і розіграють, однак результат його не сприятиме набуттю важливого для досягнення особистих і суспільних цілей у життєвих та навчальних ситуаціях комунікативного досвіду, оскільки «особисте» визначено умовою завдання.

Ситуація. Прочитайте діалог i скажіть, через що виникло непорозуміння.

У житомирському супермаркеті:

Касирка: 3 Вас 570 рублів.
Покупець (розгублено): Але я не маю рублів... Касирка (з люттю в голосі): А як можна йти до магазину без грошей?

Покупець (жартівливо): А гривнями розрахуватися можна?

Касирка (з обуренням): Ви знущаєтеся? Давайте гривні й не морочте мені голову!

Далі йде теоретичний матеріал про мовні норми й мовленнєві помилки.

На нашу думку, початкова репліка діалогу (3 опертям на яку відбувається подальший його перебіг) дещо штучна, невиправдана, адже містить лексему «рублі», яку в Україні вже давно не вживають. Оскільки ситуація, в якій діалогізують «покупець/покупчиня ↔ касир/касирка», цілком життєва, доцільно було б запропонувати діалог, де, скажімо, покупець намагається розрахуватися не готівкою, а банківською карткою (можливо, навіть вбудованою в годинник чи смартфон), у процесі перебігу якого також виникло непорозуміння. Реальність, життєвість ситуації не викликає сумнівів через те, що кожна людина була або безпосереднім учасником, або спостерігачем таких діалогів. Виникає також питання, чи достатньо (для того, щоб спонукати здобувачів освіти замислитися, як вибудувати діалог у тих чи тих обставинах) завдання «скажіть, через що виникло непорозуміння»? Чи розв'язання його уможливить набуття комунікативного досвіду здобувачами освіти? Уважаємо, що ні.

А от завдання на кшталт:

Ситуація. Упродовж тривалого часу клас готувався до свята. Учні/учениці брали участь у репетиціях, готували декорації й костюми. Напередодні виступу захворів учень, який мав слова ведучого. Одній із відповідальних учениць дали доручення вивчити його текст. Дівчина відмовлялася, пояснювала, що впродовж такого короткого терміну не встигне, але ніхто не взяв до уваги їі аргументів.

\section{Завдання:}

І. Уявіть себе в ролі учениці. Спрогнозуйте перебіг діалогів «учитель ↔ учениця», «інші учні учасники свята ↔ учениця», «вчитель ↔ учні» у випадках:

У день свята виявилося, У день свята виявищо учениця слів не вивчила лося, що учениця слова вивчила, але перехвилювалася, тому не змогла згадати текст

Розіграйте їх у парах, групах, з учителем/учителькою.

II. Дайте відповіді на запитання:

Чим краще знехтувати: думкою колективу чи власною?

Чи можна було вчинити так, щоб нікого не перевантажувати, не ображати й водночас на високому рівні відбути свято? 
Хто з учасників свята мав взяти на себе відповідальність і чому?

Такі завдання: 1) моделюють реальні життєві ситуації; 2) близькі щоденним реаліям життя учнів/ учениць (оскільки «життєві поняття, пропущені крізь призму свідомості особистості, набувають статусу індивідуального смислу, який коригує діяльність суб'єкта» [4, с. 171] у цілому, мовленнєву діяльність зокрема); 3) навчають способам соціальної й комунікативної взаємодії; 4) сприяють набуттю вмінь: а) формувати та аргументовано відстоювати власну позицію, захищати інтереси; б) орієнтуватися в перебігові комунікації, часто непрогнозованому; 5) розвивають мовлення здобувачів освіти; 6) фрормують комунікативний досвід, що в подальшому, під час виникнення конфліктних ситуацій, уможливить ефективне розв'язання їх.

Висновки. Підсумовуючи, зазначимо, що навчальний діалог слугує надійним підґрунтям для того, щоб сфрормувати в учнів/учениць уміння, зрозуміло висловлюючи думку, відстоювати власну позицію та захищати інтереси. Щоб сорормувати вміння запобігати конфоліктним ситуаціям та залагоджувати їх, потрібна достатня кількість якісних ситуативних вправ, що спонукають здобувачів освіти до навчального діалогу. Сьогодні, на жаль, у навчально-методичній літературі (зокрема, у підручниках з української мови для закладів середньої освіти) ця вимога зреалізована не вповні. Для того щоб навчальний діалог на уроках української мови не фрормально, а реально фрормував уміння здобувачів освіти запобігати конфліктним ситуаціям та залагоджувати їх, уважаємо, що автори підручників, по-перше, мають звернути увагу на кількість завдань, які моделюють комунікативні ситуації; по-друге, передбачити, щоб означені ситуації віддзеркалювали той чи той різновид конфлікту й водночас були максимально наближеними до щоденних реалій життя учнів/учениць; по-третє, фрормулюючи завдання для навчального діалогу, дати собі відповіді на такі запитання (трансорормовані із системи прийняття рішень Джонсона): «Чи зможуть учні/учениці задовольнити свої реальні потреби за результатами виконання цього завдання?», «Чи можливі варіанти вибору/різні шляхи розв'язання проблеми?», «Чи можливий єдино правильний перебіг навчального діалогу для правильного виконання завдання?», «Чи будуть учні/учениці максимально чесними самі із собою під час виконання завдання?», «Чи зможуть вони використати вже наявний власний комунікативний досвід?», «Чи знадобиться їм у подальшому здобутий за результатами виконання завдання комунікативний досвід?»

Перспектива подальших розвідок полягає у створенні системи ситуативних завдань і вправ, скерованих на формування вмінь здобувачів освіти запобігати конфліктним ситуаціям та залагоджувати їх, які можна використовувати на уроках української мови в закладах середньої освіти.

\section{БІБЛІОГРАФІЧНИЙ СПИСОК:}

1. Державний стандарт базової середньої освіти. 2020. URL: https://osvita.ua/legislation/Ser_osv/76886/.

2. Інтегрований мовно-літературний курс (українська мова, українська та зарубіжні літератури). 5-6 класи. Модельна навчальна програма / І.П. Старагіна та ін. Київ, 2021. 95 с.

3. Кулик О.Д. Поняття рефрлексії, її сутність та роль у методиці навчання української мови. Українська мова і література в школі. 2014. № 3. С. 2-7.

4. Кулик О.Д., Овсієнко Л.М., Кардаш Л.В. Українська лінгвістика : навчально-методичний посібник. Київ : Міленіум, 2013. 262 с.

5. Голуб Н.Б., Горошкіна О.М. Українська мова. 5-6 класи. Програма для закладів загальної середньої освіти. Київ, 2021. 51 с.

6. Українська мова. 5-6 класи. Модельна навчальна програма для закладів загальної середньої освіти. 5-6 класи / укл. О.В. Заболотний та ін. Київ, 2021. 65 с.

7. Девдера М.В. Українська мова. 5-6 класи. Програма для закладів загальної середньої освіти. Київ, 2021. 34 c. 